\title{
ОЖИРЕНИЕ И ЗДОРОВЬЕ СЕРДЕЧНО-СОСУДИСТОЙ СИСТЕМЫ. РЕЗУЛЬТАТЫ ИССЛЕДОВАНИЯ REWIND: СООТНОШЕНИЕ ОКРУЖНОСТИ ТАЛИИ И БЕДЕР КАК НЕЗАВИСИМЫЙ ФАКТОР РИСКА СЕРДЕЧНО-СОСУДИСТЫХ ИСХОДОВ
}

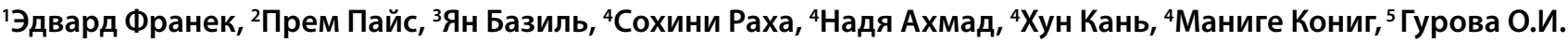 \\ 'Польская академия наук и Центральная клиническая больница MSWIA, Варшава, Польша \\ ${ }^{2}$ Научно-исследовательский институт Святого Иоанна, Бангалор, Карнатака, Индия \\ ${ }^{3}$ Медииинский университет Южной Каролины, Чарлстон, Южная Каролина, США \\ ${ }_{4}^{4}$ «ли Лилли энд Компани» (Eli Lilly and Company), Индианаполис, Индиана, США \\ ${ }^{5}$ Пер4вый Московский государственный медицинский университет им. И. М. Сеченова
}

ЦЕЛЬ: ожирение является основным фактором риска развития неблагоприятных сердечно-сосудистых событий (MACE, major adverse cardiovascular events) и смертности по причине сердечно-сосудистых заболеваний (СС3). Соотношение окружности талии и бедер (ОТБ) является доказанным фактором абдоминального ожирения и предиктором ССЗ. Целью дополнительного анализа было оценить, является ли ОТБ с поправкой на возраст и пол независимым фактором риска развития МАСЕ-3 (нефатального инфаркта миокарда [ИМ], нефатального инсульта или сердечно-сосудистой смерти) и показателя сердечно-сосудистой смертности (СС-смертности).

МАТЕРИАЛЫ И МЕТОДЫ: был проведен анализ пациентов группы плацебо в исследовании REWIND ( $\mathrm{N}=4952)$. Все пациенты имели сахарный диабет 2 типа, факторы риска СС3 или установленное ССЗ в анамнезе. Возраст пациентов составил 50 лет и старше. В течение периода наблюдения (5,4 года) были зарегистрированы сердечно-сосудистые события, входящие в MACE-3 у 663 пациентов и 346 летальных исходов по причине ССЗ. Модель пропорциональных рисков Кокса использовалась для определения, является ли ОТБ, скорректированное по возрасту и полу, значимым фактором риска для МАСЕ-3 и СС-смертности. За этим следовало изучение дополнительных факторов риска (демографических, анамнеза ССЗ и биохимических показателей) с последовательным отбором переменных для модели. Оценка показателя ИМТ была проведена аналогично ОТБ.

PЕЗУЛЬТАТЫ: ОТБ, но не ИМТ, был независимым фактором риска МАСЕ-3 и показателя смертности по причине ССЗ. Как и предполагалось, возраст и пол являлись значимыми факторами риска для обеих конечных точек, в связи с чем были скорректированы в модели. Соотношение альбумин/креатинин в моче (UACR - Urinary Albumin Creatinine Ratio), не-ЛПВП-ХC (холестерин, не связанный с липопротеидами высокой плотности) и белая раса были значимыми факторами риска развития трехкомпонентного МАСЕ. Альбумин-креатининовое соотношение, ХС ЛПНП, инфаркт миокарда в анамнезе и принадлежность к определенной расе (коренные индейцы Америки/коренные жители Аляски) являлись значимыми факторами риска показателя СС-смертности. В скорректированной модели на каждую единицу увеличения ОТБ приходилось увеличение риска МАСЕ в 3,50 раза $(p=0,013)$ и показателя СС-смертности в 5,51 раз $(p=0,005)$.

ВЫВОДЫ: ОТБ был независимым прогностическим фактором МАСЕ-3 и показателя смертности по причине СС3. Пациентам с абдоминальным ожирением и установленными ССЗ или наличием факторов риска ССЗ необходимо оценивать ОТБ и предлагать помощь в снижении массы тела.

КЛЮЧЕВЫЕ СЛОВА: REWIND; ожирение; сердечно-сосудистое здоровье; соотношение талии и бедер (СТБ) 